Article

\title{
Leakage Implications for European Timber Markets from Reducing Deforestation in Developing Countries
}

\author{
Ragnar Jonsson *, Werner Mbongo, Adam Felton and Mattias Boman \\ Southern Swedish Forest Research Centre, Swedish University of Agricultural Sciences (SLU), \\ P.O. Box 49, SE-230 53 Alnarp, Sweden; E-Mails: werner.mbongo@slu.se (W.M.); \\ adam.felton@slu.se (A.F.); mattias.boman@slu.se (M.B.) \\ * Author to whom correspondence should be addressed; E-Mail: ragnar.jonsson@slu.se; \\ Tel.: +46-4041-5186; Fax: +46-4046-2325.
}

Received: 4 July 2012; in revised form: 9 August 2012 / Accepted: 14 August 2012 /

Published: 27 August 2012

\begin{abstract}
Forest management strategies and policies such as REDD (reduced emissions from deforestation and forest degradation) may have unintentional implications for forest sectors in countries not targeted by such policies. The success of a policy effort like REDD would result in a significant reduction in deforestation and forest degradation and an ensuing reduction in the supply of natural forest timber production within participating countries. This could in turn result in price increases, inducing a supply response outside project boundaries with possible implications for forest management as well as global carbon emissions. This paper reviews the literature to discern potential timber market implications for countries sourcing wood products from developing countries affected by REDD related conservation efforts. The literature reviewed shows varying degrees of market effects leakage - policy actions in one place creating incentives for third parties to increase timber harvesting elsewhere through the price mechanism-ranging from negligible to substantial. However, wood products in the studies reviewed are dealt with on quite an aggregated scale and are assumed to be more or less perfect substitutes for wood products outside conservation effort boundaries. The review suggests that a thorough mapping of the end-uses of tropical timber is needed to comprehensively analyze impacts on wood-product markets in regions such as Europe from conservation efforts in tropical developing countries. The types of tropical timber expected to be affected, in which applications they are used, which are the most likely substitutes and where they would be sourced, are issues that, along with empirical analysis of supply and demand price
\end{abstract}


elasticities and degree of substitutability, should be investigated when assessing the overall effectiveness of REDD.

Keywords: REDD; leakage; conservation; timber market

\section{Introduction}

Policies aimed at mitigating climate change can affect forest-product markets in various ways: directly through substituting wood products for other materials that yield more greenhouse gas (GHG), via the development and use of bioenergy and biofuel, or indirectly through policies involving forest-based carbon sequestration [1-3]. The most internationally relevant climate mitigation policy with a specific focus on forests, is the United Nations collaborative initiative on Reducing Emissions from Deforestation and forest Degradation (REDD) in developing countries.

REDD is an effort to create a financial value for the carbon stored in forests, and thereby provide an incentive for developing countries to reduce emissions from forest loss [4,5]. It is concerned with: (1) designing mechanisms to make payments to developing countries for reducing emissions from deforestation and forest degradation (compared with a reference level); and (2) readiness activities, i.e., capacity building and other preparatory and demonstration activities, which prepare countries to participate in the REDD mechanism [6].

Forest management strategies and policies such as REDD targeted at developing countries may have unintentional implications for the forest sector in non-target countries. By its very design, the success of a policy effort like REDD would result in a significant reduction in deforestation and forest degradation, and consequently results in a reduction in established timber supplies within participating developing countries, which could in turn result in price increases. This price increase might induce a supply response outside project boundaries [7]. There is an important need for determining what the likely nature of such responses may be, as they have the potential to directly impact on national and international timber trade, with associated implications for the forest sector and forest management in non-target countries as well as global carbon emissions.

Europe, accounting for $32.2 \%$ of the global consumption of industrial roundwood in 2010 according to FAOSTAT, could be significantly affected by reductions in global timber supply. Here we use the available literature to discern whether timber markets (and, ultimately, forest management) in Europe are likely to be subject to leakage from targeted conservation efforts, like, e.g., REDD, in developing countries. Leakage here refers to increased timber production outside conservation areas resulting from reduced timber production within conservation areas. Such implications could result directly or indirectly from two types of leakage mechanisms: (1) activity shifting leakage; and (2) market effects leakage [8-10].

Activity shifting leakage, which concerns the displacement of baseline activities or agents from one area to the next [8], is typically a localized process, affecting smallholders or local communities in subsistence activities such as small-scale agriculture or firewood collection [9,11]. However, when deforestation agents are internationally operating logging or agribusiness companies, activity shifting 
leakage can also occur on an international level (Ibid.). This study focuses on market effects leakage though, as it is the leakage mechanism most likely to occur on international scale [9,11].

Market effects leakage occurs when policy actions in one place indirectly creates incentives for third parties to increase emissions elsewhere [8] and is caused by a shift in market equilibrium, e.g., forest-conservation projects reducing local timber supply and thus increasing prices and pressures on forests outside the project area $[9,12]$. Thus, under a REDD mechanism, a continued international demand for internationally traded commodities, i.e., timber, could lead to higher timber prices when meeting a reduced production in REDD countries; incentivizing production elsewhere and thus creating leakage [13]. By contrast, activity shifting leakage does not affect timber or other commodity prices.

In general, market effects leakage is difficult to account for due to the rapid nature of market adjustments [14], and more generally due to the difficulty of identifying cause and effect [15]. As market effects leakage is operating across international borders, it is particularly hard to quantify, as it is difficult to accurately attribute increasing emissions (or deforestation) in one country to emissions regulation (or forest conservation) in another country [13]. Hence, such leakage is not directly observable, and must instead be estimated [7].

Studies of market effects leakage are generally focused on either tracking the displacement of wood products resulting from conservation efforts in one location, so called product leakage, or tracking the displacement of carbon emissions associated with this product movement, so called carbon leakage [7]. In such studies leakage is estimated using models based upon (1) predictive simulations or (2) empirical results from market data. In addition, leakage may be estimated using analytical approaches, from which rough estimates of leakage potential can be derived from supply and demand functions (Ibid.).

This review is not strictly confined to emission displacements from carbon sequestration projects, but considers leakage from any forest conservation project irrespective of the motive for such forest retention, since the potential impacts on the exploitation of forest resources outside project areas should be the same. Hence, studies of market effects leakage which focus on either product leakage or carbon leakage from conservation efforts are included. We refer to any policy effort or project which aims to retain natural forest cover to reduce GHG emissions, or increase GHG sequestration as "conservation efforts" or "conservation projects" respectively. We discuss the available evidence for leakage likely to impact on European markets due to REDD and associated efforts, and suggest productive directions for future research of high policy relevance.

\section{Methods}

A literature search was conducted using the Web of Knowledge, Science Direct, and Scopus databases between November 2011 and March 2012. The following search-term sequence was used for all databases: carbon AND forest AND wood OR timber, with a subsequent search within these results for "leakage". This search resulted in 115 articles.

Since this paper is concerned with leakage from conservation efforts such as REDD, the studies found in the first literature search were then screened for articles dealing with leakage from conservation projects. This second search resulted in six articles deemed to be of direct relevance to 
our efforts, as indicated by assessment of their abstracts. An additional four articles were identified from their reference lists.

\section{Results and Discussion}

The results of the ten reviewed studies show varying degrees of market effects leakage (Table 1). However, two modeling studies that estimate product leakage using observed market data [16,17], provide strong inferential evidence that efforts to reduce logging in one place does tend to shift harvests elsewhere.

The magnitude of market effects leakage projected or demonstrated to occur, is shown to depend on the price elasticity of supply and demand [15]. Hence, leakage is aggravated the more price elastic the timber supply and the less price elastic the timber demand. That is, leakage worsens the more responsive supply and the less responsive demand is to changes in price. The effect of price elasticity of supply on market effects leakage is demonstrated in Figure 1 below.

Consider REDD and similar policy measures as subsidies. Their implementation would imply an upward shift of the supply curve of the targeted countries, since harvesting forest may now entail an additional cost in terms of subsidy foregone. Possibly, the entire supply from a particular market segment could be removed as a result, as is the case in Figure 1. This reduced supply may induce a supply response outside project boundaries [7]. The demand $\left(\mathrm{D}_{\mathrm{N}}\right)$ facing the non-conservation market segment in Figure 1 can be regarded a residual demand, i.e. the market demand that is not met by the conservation market segment at any price. This can be derived as total market demand minus the supply from the conservation segment. Actual absolute leakage in this case is equal to the distance A in Figure 1. The relative leakage - a better measure of the effectiveness of the conservation policy - can be calculated as the quota A/B. The effect ultimately depends on the relative slopes of the supply and demand curves, i.e., demand and supply elasticity. In Figure 1, the upper panel shows that the leakage effect is smaller when the supply in the non-conservation segment is relatively inelastic, whereas it is greater when the supply is relatively elastic (bottom panel).

As is apparent from Table 1, wood products in the studies with a global scope are in general dealt with on a quite aggregated scale. With one exception, i.e., Gan and McCarl [18], these studies do not address the issue of substitutability. Wood products in conservation sites (within project boundaries) and in the locations where leakage take place are apparently, at least implicitly, assumed to be more or less perfect substitutes (i.e., identical products from a consumer perspective). As such, the degree of leakage could be exaggerated in some of the modeling studies having a global scope, as leakage diminishes if the timber supplied from non-reserved forests is a poor demand substitute for the timber retained in reserved forests, as shown by Murray et al. [15]. In this case, the outward shift of the demand curve $\left(D_{N}\right)$ at the baseline price $P_{0}$ in Figure 1 would be less than the quantity supplied by supply segment $\mathrm{R}\left(\mathrm{S}_{\mathrm{R}}\right)$ should the conservation policy not be in effect (in the extreme case of zero substitutability, i.e., independent markets, there would be no shift in demand function $\mathrm{D}_{\mathrm{N}}$ and hence no market effects leakage).

Sensitivity analysis as regards the degree of substitutability by Gan and McCarl [18] do not show any significant change in product leakage. However, they only apply a ten percent change in the elasticity of substitution between domestic and imported forestry products. Further, actual trade 
patterns indicate at least some substitutability between temperate and tropical timber. Hence, temperate supplying countries have increased their share of the European sawn hardwood market, at the expense of tropical countries [19]. Oak thus has consolidated its dominant market position in the European flooring and joinery sectors, as tropical hardwoods has continued to lose market share [19].

Table 1. Leakage drivers, magnitude and geographical scope.

\begin{tabular}{|c|c|c|c|c|c|}
\hline \multicolumn{6}{|c|}{ Modeling } \\
\hline Study id & $\begin{array}{c}\text { Estimation } \\
\text { approach }\end{array}$ & Drivers & $\begin{array}{l}\text { Geographical } \\
\text { leakage scale }\end{array}$ & Leakage magnitude & $\begin{array}{c}\text { Type of } \\
\text { product(s) }\end{array}$ \\
\hline 1 & $\begin{array}{l}\text { Predictive } \\
\text { simulation }\end{array}$ & $\begin{array}{l}\text { Timber } \\
\text { markets }\end{array}$ & Global & $\begin{array}{l}\text { Overall (all sectors) leakage of } 28 \% \text {, } \\
\text { reduced by } 0.01 \%-0.02 \% \text { with the inclusion } \\
\text { of forestry mitigation. }\end{array}$ & "timber" \\
\hline 2 & $\begin{array}{l}\text { Predictive } \\
\text { simulation }\end{array}$ & $\begin{array}{l}\text { Overall } \\
\text { markets }\end{array}$ & Global & $\begin{array}{c}\text { Overall leakage } 45 \% \text {, } \\
12 \% \text { with REDD credits }\end{array}$ & n.s. \\
\hline 3 & $\begin{array}{l}\text { Predictive } \\
\text { simulation }\end{array}$ & $\begin{array}{l}\text { Timber } \\
\text { markets }\end{array}$ & Global & Around $50 \%$ on average & n.s. \\
\hline 4 & $\begin{array}{l}\text { Predictive } \\
\text { simulation }\end{array}$ & $\begin{array}{l}\text { Timber and } \\
\text { agricultural } \\
\text { markets }\end{array}$ & regional USA & $\begin{array}{c}\text { Logging set-aside: } \\
16 \% \text { (set-aside in Pacific-northwest) to } 68 \% \\
\text { (set-aside in South-central) }\end{array}$ & "timber" \\
\hline 5 & $\begin{array}{l}\text { Predictive } \\
\text { simulation }\end{array}$ & $\begin{array}{l}\text { Timber } \\
\text { markets }\end{array}$ & global & $42 \%$ (Canada) to $95 \%$ (Russia) & $\begin{array}{l}\text { lumber and wood } \\
\text { products sector, } \\
\text { pulp and paper } \\
\text { sector }\end{array}$ \\
\hline 6 & $\begin{array}{l}\text { Predictive } \\
\text { simulation }\end{array}$ & $\begin{array}{l}\text { Timber } \\
\text { markets }\end{array}$ & National & $\begin{array}{l}2 \% \text { (elastic demand of }-13 \text { ), } \\
38 \% \text { (inelastic demand of }-0.5 \text { ) }\end{array}$ & "Boards" \\
\hline 7 & $\begin{array}{l}\text { Predictive } \\
\text { simulation }\end{array}$ & $\begin{array}{l}\text { Timber } \\
\text { markets }\end{array}$ & global & $5 \%$ in area terms & $\begin{array}{l}\text { "timber logs" } \\
\text { (industrial round } \\
\text { wood) }\end{array}$ \\
\hline 8 & Empirical & $\begin{array}{l}\text { Timber and } \\
\text { agricultural } \\
\text { markets }\end{array}$ & global & $\begin{array}{c}22 \% \text { for wood and agricultural products } \\
\text { combined; } 74 \% \text { considering wood } \\
\text { products only }\end{array}$ & $\begin{array}{l}\text { raw, primary and } \\
\text { secondary-wood } \\
\text { products }\end{array}$ \\
\hline 9 & Empirical & $\begin{array}{l}\text { Timber } \\
\text { markets }\end{array}$ & (N America) & $\begin{array}{c}\text { Total (Continental) } 84 \%, \\
\text { transnational (to Canada) } 26 \%\end{array}$ & softwood lumber \\
\hline \multicolumn{6}{|c|}{ Analytical approach } \\
\hline Study id & \multicolumn{2}{|c|}{ Drivers } & $\begin{array}{l}\text { Geographical } \\
\text { leakage scale }\end{array}$ & Leakage magnitude & $\begin{array}{c}\text { Type of } \\
\text { product(s) }\end{array}$ \\
\hline 4 & \multicolumn{2}{|c|}{$\begin{array}{c}\text { Timber and agricultural } \\
\text { markets }\end{array}$} & transnational & $\begin{array}{l}47 \% \text {, assuming unitary elasticities of supply } \\
\qquad(1.0) \text { and demand }(-1.0)\end{array}$ & "timber" \\
\hline 5 & \multicolumn{2}{|c|}{ Timber markets } & transnational & n.s. & "timber" \\
\hline 10 & \multicolumn{2}{|c|}{ Timber markets } & global & from 0 to over $100 \%$ & n.s. \\
\hline
\end{tabular}

Note: n.s. = not specified. Leakage magnitude refers to increased carbon emissions or timber production outside conservation areas as a share of reduced emissions or timber production within conservation areas (i.e., relative leakage). The studies referred to in Table 1 are labelled as follows: 1. Michetti and Rosa [20]; 2. Bosello et al. [21]; 3. Sun and Sohngen [22]; 4. Murray et al. [15]; 5. Gan and McCarl [18]; 6. Sohngen and Brown [23]; 7. Sohngen et al. [12]; 8. Meyfroidt et al. [17]; 9. Wear and Murray [16]; 10. Magnani et al. [24]. 
Figure 1. Market effects leakage from forest conservation: $(\mathbf{a}, \mathbf{b})$ a two-country case assuming perfect substitutability, adapted from Murray et al. [15].

(a) Case 1: less price elastic supply in non-conservation market segment compared to Case 2.
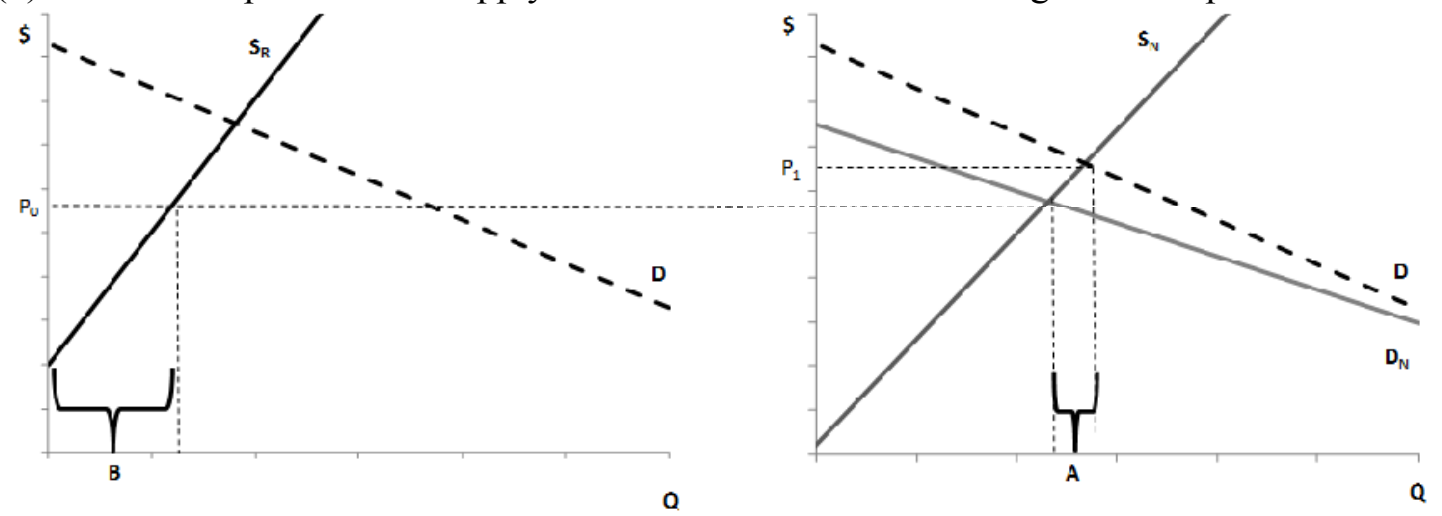

(b) Case 2: more price elastic supply in non-conservation market segment compared to Case 1 .
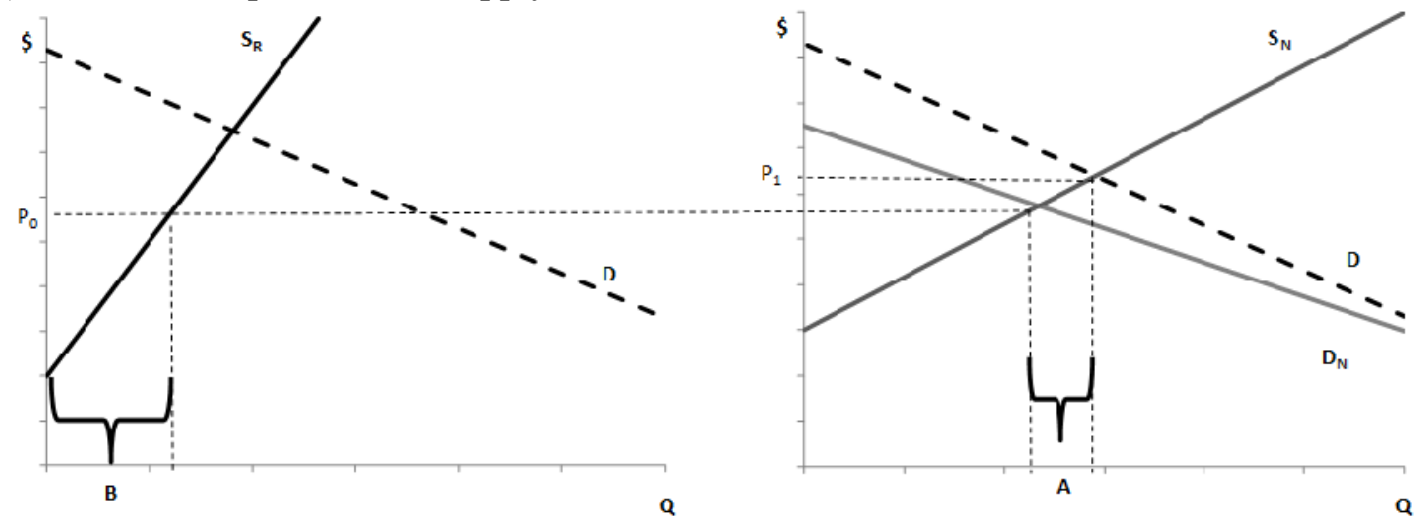

Note: $\mathrm{D}=$ total demand; $\mathrm{S}_{\mathrm{R}}=$ supply from forests considered for conservation (prior to policy implementation); $\mathrm{B}=$ harvesting in forests considered for conservation at baseline price $\mathrm{P}_{0}$ (prior to policy implementation); $\mathrm{D}_{\mathrm{N}}=$ demand facing non-conservation sources $=$ residual demand $=\mathrm{D}-\mathrm{S}_{\mathrm{R}}$; $\mathrm{S}_{\mathrm{N}}=$ supply from non-conservation sources = total supply after policy implementation; $\mathrm{A}=$ Absolute leakage; $\mathrm{A} / \mathrm{B}=$ relative leakage.

It is shown theoretically that the magnitude of leakage depends on the degree of cooperation in conservation efforts among countries. Thus, partial cooperation alone, i.e., when covered countries have a collectively limited impact in the global market, may not lead to a significant reduction in leakage [15]. Though small in an absolute sense, relative leakage (increased carbon emissions or timber production outside conservation areas as a share of reduced emissions or timber production within conservation areas) would be considerable [15]. Predictive simulations in Gan and McCarl [18] echo this theoretically derived conclusion. In this connection it is worthwhile to mention that FAOSTAT data indicate that the sixteen countries receiving support to national programs within the UN-REDD Programme (Democratic Republic of the Congo, Nigeria, Republic of Congo, Tanzania, Zambia, Cambodia, Indonesia, Papua New Guinea, Solomon Islands, Sri Lanka, the Philippines, Vietnam, Bolivia, Ecuador, Panama and Paraguay) together accounted for $15.5 \%$ and $12.2 \%$ of the world production of non-coniferous industrial roundwood and sawnwood respectively in 2010 . 
Two of the studies reviewed deal explicitly with product leakage from tropical countries/regions. Estimations based on observed market data in Meyfroidt et al. [17] and predictive simulations in Gan and McCarl [18] indicate considerable leakage respectively from forest conservation in individual tropical developing countries and when cooperation in forest conservation takes place among tropical forest regions alone. The circumstance that product leakage is estimated through net imports of wood products in [17] presupposes perfect substitutability between reserved and non-reserved timber, in the sense that the same wood products are exported and imported. Indeed, most of the imported wood also come from other tropical developing countries [17], which makes this assumption of perfect substitution more reasonable. Further, as illegal trade is not recorded in the trade databases used; net displacements/leakage is underestimated for countries importing illegally traded timber and overestimated for countries supplying illegal timber [17]. The estimate of leakage in Meyfroidt et al. [17] also fails to recognize that displaced/leaked wood production may be traded to third countries, thus potentially underestimating product leakage.

\section{Conclusions}

All in all, the literature - though differing as to the magnitude - suggests that conservation efforts in tropical developing countries could result in increased utilization of forest resources in other world regions such as Europe. In this context it is worth noting that current trade patterns provide some support for the assumption of substitutability among wood products originating in different countries or regions. Should REDD prove successful it would result in a reduction in tropical timber supply, thereby reinforcing the current trend of declining market share for tropical timber.

Should the targeted countries have a collectively small impact in the global timber market, the avoided deforestation actions would be especially prone to leakage. As the supply contraction could be easily replaced by increased supply elsewhere, such leakage would be particularly difficult to identify. As shown by FAOSTAT data though, the countries receiving support to national programs within the UN-REDD Programme account for a non-trivial share of world production and exports of non-coniferous roundwood and sawnwood. Though these shares include plantations which are not targeted by conservation efforts, REDD could potentially incur considerable market leakage, in absolute terms.

As indicated by actual trade patterns - temperate hardwoods substituting for tropical hardwoods in Europe - there seems to be scope for increasing the market share for European hardwoods, apparently particularly so for oak. Indeed, already in 2010 there was an increased pressure on supplies of oak logs in France and Germany [19]. Conservation efforts such as REDD in tropical countries could contribute to this development. The market effects of conservation efforts in tropical countries could be particularly significant in specific applications, such as flooring and joinery.

A comprehensive analysis of potential impacts in importing regions like Europe of conservation in tropical developing countries should include a thorough mapping of end-uses of tropical timber. Thus, assessing the overall effectiveness of REDD, issues such as what types of tropical timber are primarily expected to be affected, in what applications they are used, which are the most likely substitutes and where they would be sourced need to be addressed, along with empirical analysis of supply and 
demand price elasticities and the degree of substitutability in the relevant markets. In particular, policy makers in Europe need to ensure such substitutes for tropical timber come from sustainable sources.

\section{Acknowledgments}

The research was funded through Future Forests, a multi-disciplinary research program supported by Mistra (the Foundation for Strategic Environmental Research), the Swedish Forestry Industry, the Swedish University of Agricultural Sciences, Umeå University, and the Forestry Research Institute of Sweden.

\section{Conflict of Interest}

The authors declare no conflict of interest.

\section{References}

1. Binkley, C.S.; van Kooten, G.C. Integrating climatic change and forests: Economic and ecologic assessments. Clim. Chang. 1994, 28, 91-110.

2. European-Commission. Proposal for a Directive of the European Parliament and of the Council on the Promotion of the Use of Energy from Renewable Sources; European-Commission: Brussels, Belgium, 2008.

3. UN-REDD. About the UN-REDD Programme; UN-REDD Programme: Geneva, Switzerland, 2009.

4. Holmgren, L. International Forest Policy-An Overview; Report from the secretariat for international forestry issues; The Royal Swedish Academy of Agriculture and Forestry: Stockholm, Sweden, 2010.

5. UN-REDD. About REDD+; UN-REDD Programme: Geneva, Switzerland, 2009.

6. Angelsen, A.; Wertz-Kanounnikoff, S. What are the key design issues for REDD and the criteria for assessing options. In Moving Ahead with REDD: Issues, Options and Implications; CIFOR: Bogor, Indonesia, 2008.

7. Murray, B.C. Leakage from an Avoided Deforestation Compensation Policy: Concepts, Empirical Evidence, and Corrective Policy Options; Nicholas Institute for Environmental Policy Solutions, Duke University: Durham, NC, USA, 2008.

8. Aukland, L.; Costa, P.M.; Brown, S. A conceptual framework and its application for addressing leakage: The case of avoided deforestation. Clim. Policy 2003, 3, 123-136.

9. Schwarze, R.; Niles, J.O.; Olander, J. Understanding and managing leakage in forest-based greenhouse-gas-mitigation projects. Philos. Trans. R. Soc. Lond. Series A 2002, 360, 1685-1703.

10. IPCC. Special Report on Land Use, Land-Use Change, and Forestry; Intergovernmental Panel on Climate Change: Geneva, Switzerland, 2000.

11. Henders, S.; Ostwald, M. Forest carbon leakage quantification methods and their suitability for assessing leakage in REDD. Forests 2012, 3, 33-58.

12. Sohngen, B.; Mendelsohn, R.; Sedjo, R. Forest management, conservation, and global timber markets. Am. J. Agric. Econ. 1999, 81, 1-13. 
13. Skutsch, M.M.; McCall, M.K. Reassessing REDD: Governance, markets and the hype cycle. Clim. Chang. 2010, 100, 395-402.

14. McKinley, D.C.; Ryan, M.G.; Birdsey, R.A.; Giardina, C.P.; Harmon, M.E.; Heath, L.S.; Houghton, R.A.; Jackson, R.B.; Morrison, J.F.; Murray, B.C.; Pataki, D.E.; Skog, K.E. A synthesis of current knowledge on forests and carbon storage in the United States. Ecol. Appl. 2011, 21, 1902-1924.

15. Murray, B.C.; McCarl, B.A.; Lee, H.C. Estimating leakage from forest carbon sequestration programs. Land Econ. 2004, 80, 109-124.

16. Wear, D.N.; Murray, B.C. Federal timber restrictions, interregional spillovers, and the impact on US softwood markets. J. Environ. Econ. Manag. 2004, 47, 307-330.

17. Meyfroidt, P.; Rudel, T.K.; Lambin, E.F. Forest transitions, trade, and the global displacement of land use. Proc. Natl. Acad. Sci. U.S.A. 2010, 107, 20917-20922.

18. Gan, J.; McCarl, B.A. Measuring transnational leakage of forest conservation. Ecol. Econ. 2007, 64, 423-432.

19. Clark, D. Forest Products Annual Market Review 2010-2011; Geneva Timber and Forest Study Paper \#20123064737; United Nations Economic Commission for Europe: Geneva, Switzerland, 2011.

20. Michetti, M.; Rosa, R. Afforestation and Timber management compliance strategies in climate Policy-A Computable general equilibrium analysis. Clim. ChangeS 2011, FEEM Note di lavoro No. 2011.004. Available online: http://www.feem.it/userfiles/attach/2011118158514NDL2011004.pdf (accessed on 14 August 2012).

21. Bosello, F.; Eboli, F.; Parrado, R.; Rosa, R. EU-Mitigation, REDD and the Carbon Market: A General Equilibrium Assessment; CMCC Research Paper No. 94; Centro Euro-Mediterraneo per i Cambiamenti Climatici: Bologna, Italy, 2010; Available online: http://papers.ssrn.com/sol3/ papers.cfm?abstract_id=1676734 (accessed on 20 August 2012).

22. Sun, B.; Sohngen, B. Set-asides for carbon sequestration: Implications for permanence and leakage. Clim. Chang. 2009, 96, 409-419.

23. Sohngen, B.; Brown, S. Measuring leakage from carbon projects in open economies: A stop timber harvesting project in Bolivia as a case study. Can. J. For. Res. 2004, 34, 829-839.

24. Magnani, F.; Dewar, R.C.; Borghetti, A. Leakage and spillover effects of forest management on carbon storage: Theoretical insights from a simple model. Tellus Ser. B 2009, 61, 385-393.

(C) 2012 by the authors; licensee MDPI, Basel, Switzerland. This article is an open access article distributed under the terms and conditions of the Creative Commons Attribution license (http://creativecommons.org/licenses/by/3.0/). 